\title{
EPA in schizophrenia and violence
}

lan $\mathrm{H}$ Treasaden

\author{
From $1^{\text {st }}$ International Congress on Neurobiology and Clinical Psychopharmacology and European \\ Psychiatric Association Conference on Treatment Guidance \\ Thessaloniki, Greece. 19-22 November 2009
}

This lecture will describe the role of EPA in schizophrenia and violence by first considering fatty acid metabolism abnormalities in violence and in schizophrenia.

The results of the first 31-phosphorus magnetic resonance spectroscopy study of cerebral metabolism in patients with schizophrenia who have seriously and dangerously violently offended will then be described, which found a significantly lower beta-NTP and significantly higher gamma-NTP level in the patient group compared with age- and gender-matched control subjects. To explore these findings further, the relationship between these neurospectroscopy results and the volumetric niacin response (VNR) was studied. A significant negative correlation (Spearman $\mathrm{r}=-0.78, \mathrm{P}<0.005$ ) was found between the VNR and cerebral Pi. The implications of this finding will be discussed. The further findings of our group relating to motion-restricted membrane phospholipids in the brain, measures of oxidative stress and changes in brain structure in patients with schizophrenia who have seriously and dangerously violently offended will be detailed.

Finally, the implications of our results for the role of EPA in schizophrenia and violence will be described.

Published: 22 April 2010

doi:10.1186/1744-859X-9-S1-S24

Cite this article as: Treasaden: EPA in schizophrenia and violence. Annals

of General Psychiatry 2010 9(Suppl 1):S24.

Lipid Neuroscience Group, Imperial College London and Consultant in Forensic Psychiatry, Three Bridges Unit, West London Mental Health Trust, Middlesex, UK

Submit your next manuscript to BioMed Central and take full advantage of:

- Convenient online submission

- Thorough peer review

- No space constraints or color figure charges

- Immediate publication on acceptance

- Inclusion in PubMed, CAS, Scopus and Google Scholar

- Research which is freely available for redistribution

Submit your manuscript at www.biomedcentral.com/submit
() Biomed Central 